\title{
Difficulties of access to health services among non-institutionalized older adults: prevalence and associated factors
}

Priscila Karolline Rodrigues Cruz' $\mathbb{I D}$ Maria Aparecida Vieira² ${ }^{\text {ID }}$ Jair Almeida Carneiro,4 $\mathbb{1}$ Fernanda Marques da Costa 23,4 (ID Antônio Prates Caldeira ${ }^{4,5}$ ID

\section{Abstract}

Objective: To estimate the prevalence and factors associated with the difficulties of access to health services among non-institutionalized older adults in the town of Montes Claros, Minas Gerais, Brazil. Method: A cross-sectional study nested in a population-based cohort of community-dwelling older adults was carried out in Montes Claros, Minas Gerais, Brazil. Data collection was performed in the homes of the older adults between November 2016 and February 2017. Demographic, socioeconomic, and health-related variables and access to and use of health services were evaluated. Bivariate analyzes (Pearson's chi-squared test) were conducted, adopting a level of significance lower than 0.20 for inclusion of the independent variables in the multiple model. The final model was generated by Poisson regression analysis, with robust variance, and the variables maintained were associated with difficulty in using the health services up to a level of significance of 0.05 ( $p<0.05)$. Results: 394 older adults participated in this study, 33\% of whom reported difficulties with access. In multiple analysis, greater difficulty of access was registered among older adults without a partner; who could not read; were frail and had a negative self-perception of health. Older adults face greater difficulties with access when seeking public services. Conclusion: A high perception of difficulty with access was identified, determined by social and physical aspects inherent to aging, and which may be worsened by the characteristics of public services. There is a need for investments in the health care of older adults, in order to guarantee care that promotes healthy aging.

\footnotetext{
Universidade Estadual de Montes Claros, Centro de Ciências Biológicas e da Saúde, Programa de Pósgraduação em Cuidado Primário em Saúde. Montes Claros, MG, Brasil.

2 Universidade Estadual de Montes Claros, Centro de Ciências Biológicas e da Saúde, Departamento de Enfermagem, Programa de Pós-graduação em Cuidado Primário em Saúde. Montes Claros, MG, Brasil.

3 Universidade Estadual de Montes Claros, Centro de Ciências Biológicas e da Saúde, Departamento de Saúde Mental e Saúde Coletiva. Montes Claros, MG, Brasil.

4 Centro Universitário FIPMoc de Montes Claros, Departamento de Medicina. Montes Claros, MG, Brasil.

5 Universidade Estadual de Montes Claros, Centro de Ciências Biológicas e da Saúde, Departamento de Saúde da Mulher e da Criança. Montes Claros, MG, Brasil
}

The authors declare there are no conflicts of interest in relation to the present study.

No funding was received in relation to the present study.

Keywords: Health Services. Old Age Assistance. Health Services Accessibility. Prevalence. Community Health Nursing. 


\section{INTRODUCTION}

Changes in demographic patterns and increased longevity are trends that have redesigned the age structure of the population, both in Brazil and on a global scale ${ }^{1,2}$. This scenario requires changes in the structure and provision of fundamental health services, establishing standards of quality and ensuring that allow older adults are allowed to live not only longer, but actively and healthily ${ }^{2,3}$.

Based on this paradigm of healthy aging emerges the need for adaptations to the health system to ensure quality of access and use of health services. These adjustments suggest the reformulation of health policies to include new forms of care, based on improvements in quality of life, the maintaining of functional ability and the prevention of chronic health conditions ${ }^{2}$. In other words, models of care that respect the characteristics of older adults and envisage integrated care throughout the care pathway ${ }^{4}$.

Access to health services is an important factor that underlies the quality and effective performance of such services ${ }^{5}$. Access is a set of dimensions that determine the relationship between the demand for and entry into the service ${ }^{6}$. The use of health services comprises all direct contact with points of care and is evidence that access has been achieved ${ }^{6}$.

The relationship of aging and access can be considered a worrying situation. Characteristics inherent to aging present, as a consequence, less physical willingness on the part of older adults to seek health services and to move between different levels of care ${ }^{7}$. Other factors associated with the morbidity profile, such as geographical and socioeconomic variations; individual needs; quality of life; and level of health knowledge are determinant in the use of health services and how often they are used and, therefore, may determine difficulties in access to health services for the older adult population ${ }^{8}$.

The difficulties of access to health services go far beyond geographical aspects, and are mainly related to the insufficient supply of services'. In addition, organizational aspects should be considered, namely economic; social; cultural; religious and epidemiological factors, and communication with health teams ${ }^{9,10}$.
In a general sense, there are still gaps in knowledge about access to and use of health services. Most studies are based on the needs of those who are already present in such services, demographic characteristics and the most prevalent health problems ${ }^{11}$. Studies conducted with users of health services exclude those not seeking care, and hamper knowledge at a population level ${ }^{11}$. Therefore, population-based studies are warranted. In addition, it is clear that there is little uniformity in the process of analyzing the difficulty of access to health services, which represents an obstacle for comparative investigation of the literature and highlights the need for further studies in the area ${ }^{12}$.

Estimating the prevalence and identifying factors associated with poor access to health services emphasizes the real situation regarding access for older adults and contributes to raising the awareness, through reliable data, of managers and health professionals about the need for adaptations, interventions, knowledge and planning of public policies in order to promote the expansion of access, reception and care that is decisive if aging with quality is to be achieved ${ }^{12}$.

In terms of health professionals, the present study can stimulate a need for training and changes in the organization of work processes in order to provide older adults with access to quality health services. Frailty, morbidity and other determinants are barriers to access to health and recognizing them is important for professionals working in health services, family members, and those involved in the intake and integrated care of older adults ${ }^{8}$.

It is also important to highlight that the north of the state of Minas Gerais, where the present study is located, represents one of the most deprived regions in Brazil and has human development indexes that are among the lowest in the state and, therefore, requires research related to health care for older adults, including the assessment of possible difficulties in access and their determinants ${ }^{13}$. In this context, the study aimed to estimate the prevalence of difficulties in access to health services among noninstitutionalized older adults in the city of Montes Claros, Minas Gerais, Brazil, and identify factors associated with the same. 


\section{METHOD}

This is a cross-sectional study nested in a population-based cohort conducted in the municipal region of Montes Claros, in the north of the state of Minas Gerais, Brazil, which has a population of approximately 404,000 inhabitants and represents the main regional urban center ${ }^{14}$.

The sample size at baseline was calculated to estimate the prevalence of each health outcome investigated in the epidemiological survey, considering an estimated population of 30,790 older adults $(13,127$ men and 17,663 women) living in the urban region, according to 2010 census data from the Brazilian Institute of Geography and Statistics (or IBGE); a 95\% confidence level; a conservative prevalence of $50 \%$ for unknown outcomes and a sampling error of $5 \%$. As cluster sampling was used, the number identified was multiplied by a correction factor and delineation effect (deff) of $1.5 \%$, plus $15 \%$ for any losses. The minimum number of older persons defined by the sample calculation was 360 (baseline).

The baseline sampling process was probabilistic, by cluster and in two stages. In the first stage, the census tract was used as the sampling unit. Fortytwo census tracts were randomly selected among the 362 urban sectors in the municipal region, according to IBGE data ${ }^{14}$. In the second stage, the number of households was defined according to the population density of individuals aged 60 years or older. At this stage, more households were allocated from the sectors with the largest number of older adults, in order to produce a more representative sample of the population. After the households were drawn, checks were carried out to see if the selected house contained older residents. If not, the researchers checked if the household to the left or right contained such individuals.

Data collection was performed between November 2016 and February 2017. The inclusion criterion was 60 years of age or older. Older people who were not available to participate following at least three visits on different days and at different times, even with prior appointment, were considered losses, as well as older adults whose caregivers/family members refused to participate in the study.
The data collection instrument used was based on similar population-based studies ${ }^{15,16}$. Specifically, the dimension of access was adapted from the Ministry of Health's Vigitel 2010 survey $^{17}$, and was previously tested in this research project through a pilot study in a specially selected census tract, the data of which were not included in the final survey. The process of form completion, verifying data consistency and quality control, as well as storing the information was coordinated by the principal investigator.

The interviewers (undergraduate students in Nursing and Medicine) were previously trained and calibrated, with the Kappa agreement measure (0.8) used. For data collection, the census tracts were traversed from a previously defined point in each tract, for the carrying out of the interviews. The questionnaire questions were answered with the help of family members or caregivers for those older adults who were unable to respond, following the guidelines of the data collection instruments.

The demographic, social and economic characteristics of the group were evaluated; as well as variables related to health care and access to and use of health services. Frailty was assessed using the Edmonton Frail Scale (EFS) scale ${ }^{18}$. The perception of difficulty in using the most sought after health service was also assessed, through the question "Do you have any difficulty in using your main health service when you need it?". The answer to this question was taken as a dependent variable and was dichotomized as yes or no.

The independent variables studied were: demographic: sex (male and female), age group (dichotomized as up to 79 years old and equal to or above 80 years old, due to a worsening of frailty in this age group). Social: marital status (with or without partner), condition of living alone or with others, education (up to 4 years of schooling or more than 4 years), reading (knowing how to read or not). Economic: own income, monthly family income (up to 1 minimum wage or more than 1 minimum wage). Medical: presence of chronic comorbidities (hypertension, diabetes mellitus, acute myocardial infarction, osteoarticular diseases, neoplasia, stroke). Self-perceived health, presence of caregiver, falls in the last 12 months, hospitalization in the last 12 
months, frailty. Relating to access: transportation difficulties, financial difficulties, absence of company, poor health services, geographical and architectural barriers, as well as the time needed to reach the health service. Having a health plan, the main type of service sought (public or private), types of service that the individual found most difficult to access: private emergency care, unified national health service (or SUS), specialty center and basic unit of the Family Health Strategy (FHS).

Frailty was assessed using the Edmonton Frail Scale $(\mathrm{EFS})^{18}$, an instrument that assesses nine domains: cognition; health condition; functional independence; social support; use of medication; nutrition; mood; urinary continence and functional performance. These domains are divided into 11 items, with a score from 0 to 17 . For statistical analysis, the scale results were divided into two levels: not frail (final score $\leq 6$ ) and frail (score $>6$ ).

The analysis of the results involved the construction of a spreadsheet in the Excel ${ }^{\circledR}$ program, for organization and double entry of data with conferring and comparison of such data entry. The information was coded and transferred to a database of the analytical software program the Statistical Package for Social Sciences - SPSS, version 18.0, (SPSS for Windows, Chicago, USA), in order to evaluate possible relationships of association between the variables.

Bivariate analyzes were performed to identify factors associated with the response variable using the chi-squared test. The magnitude of the associations was estimated from the prevalence ratio (PR). Poisson regression with robust variance was used to calculate the adjusted PR, considering, jointly, the independent variables most strongly associated with difficulty with access in the bivariate analysis, up to a $20 \%$ significance level $(p<0.20)$. For the analysis of the final model, a significance level of $0.05(p<0.05)$ was considered.

The study complied with Resolution $\mathrm{N}^{\circ}$ 466, dated 12 December 2012, of the National Health Council/ Ministry of Health, which establishes guidelines and standards that regulate studies involving human beings. The study was approved by the Research Ethics Committee of the Faculdades Integradas Pitágoras (Pitágoras Integrated Colleges) de Montes Claros under Opinion n ${ }^{\circ} 1629.395$ 08/07/2016 and CAAE $n^{\circ}$ 56520216.4.0000.5109. All of the older adults signed a Free and Informed Consent Form in relation to their participation in the study.

\section{RESULTS}

A total of 394 older community members participated in this study. The evaluation of the sample characteristics showed a predominance of women, $263(66.8 \%)$. The most prevalent age group was between 60 and 79 years old, $302(76.6 \%)$, with a mean age of 73.9 (sd \pm 7.9 ) years. A total of 199 $(50.6 \%)$ older adults lived without a partner; 295 $(74.9 \%)$ had up to four years of schooling. In terms of the social variables, $348(88.3 \%)$ older adults did not have a caregiver. Of the medical variables, 281 $(71.3 \%)$ were hypertensive; $189(48.0 \%)$ reported osteoarticular diseases.

The most sought after health services were Family Health Strategies, 259 (65.7\%), followed by Emergency Room, 188 (47.7\%). Private or health insurance services (plans) were sought by 132 (33.5\%) older adults. A total of 122 (17.8\%) older adults were hospitalized in the 12 months prior to the survey.

Regarding access issues, the principal difficulties in accessing the main health service were: transportation difficulties, 39 (30\%), lack of financial resources, 32 (24.6\%), lack of company, $30(23.1 \%)$, the perception that the service was poor, 58 (44.6\%), architectural barriers, 24 (18.5\%), geographic barriers, 28 (21.5\%). The average time taken to reach the main service was 16.4 minutes.

Table 1 shows the bivariate analysis of the difficulty of access to health services according to demographic, socioeconomic and health variables and access to health services data.

Table 2 shows the factors associated with the difficulty of access to health services among community-dwelling older adults. 
Table 1. Bivariate analysis of the difficulty of access to health services according to demographic, socioeconomic and health variables and access to health services data (n=394). Montes Claros, Minas Gerais, Brazil, 2018.

\begin{tabular}{|c|c|c|c|c|}
\hline \multirow{3}{*}{ Independent Variables } & \multirow{3}{*}{$\begin{array}{l}\text { Sample } \\
\text { n }(\%)\end{array}$} & \multicolumn{3}{|c|}{ Difficulty with access } \\
\hline & & Yes & No & \\
\hline & & $\mathrm{n}(\%)$ & $\mathrm{n}(\%)$ & $\mathrm{p}$-value \\
\hline \multicolumn{5}{|l|}{ Demographic Characteristics } \\
\hline Sex & & & & 0.463 \\
\hline Male & $131(33.2)$ & $40(30.5)$ & $91(69.5)$ & \\
\hline Female & $263(66.8)$ & $90(34.2)$ & $173(65.8)$ & \\
\hline $\begin{array}{l}\text { Age range (years) } \\
\text { (mean } 73.9 \pm 7.9)\end{array}$ & & & & 0.928 \\
\hline Up to 79 & $302(76.6)$ & $100(33.1)$ & $202(69.9)$ & \\
\hline$\geq 80$ & $92(23.4)$ & $30(32.6)$ & $62(67.4)$ & \\
\hline \multicolumn{5}{|l|}{ Social Characteristics } \\
\hline Marital status & & & & 0.004 \\
\hline With partner & $195(49.5)$ & $51(26.2)$ & $144(73.8)$ & \\
\hline Without partner & $199(50.6)$ & $79(39.7)$ & $120(60.3)$ & \\
\hline Living arrangement & & & & 0.036 \\
\hline Lives alone & $50(12.7)$ & $107(31.1)$ & $237(68.9)$ & \\
\hline Does not live alone & $344(87.3)$ & $23(46.0)$ & $27(54.0)$ & \\
\hline Schooling (years) & & & & 0.032 \\
\hline$>4$ & $295(74.9)$ & $24(24.2)$ & $75(75.8)$ & \\
\hline Up to 4 & $99(25.1)$ & $106(35.9)$ & $189(64.1)$ & \\
\hline Can read & & & & 0.006 \\
\hline Yes & $300(76.1)$ & $88(29.3)$ & $212(70.7)$ & \\
\hline No & $94(23.9)$ & $42(44.7)$ & $52(55.3)$ & \\
\hline \multicolumn{5}{|l|}{ Economic Factors } \\
\hline Own income & & & & 0.755 \\
\hline Yes & $355(90.1)$ & $118(33.2)$ & $237(66.8)$ & \\
\hline No & $39(9.9)$ & $12(30.8)$ & $27(69.2)$ & \\
\hline Monthly household income (minimum wage*) & & & & 0.041 \\
\hline$>1$ & $292(74.1)$ & $88(30.1)$ & $204(69.9)$ & \\
\hline Up to 1 & $102(25.9)$ & $42(41.2)$ & $60(58.8)$ & \\
\hline \multicolumn{5}{|l|}{ Medical factors } \\
\hline Arterial hypertension & & & & 0.137 \\
\hline No & $113(28.7)$ & $31(27.4)$ & $82(72.6)$ & \\
\hline Yes & $281(71.3)$ & $99(35.2)$ & $182(64.8)$ & \\
\hline Diabetes mellitus & & & & 0.346 \\
\hline No & $304(77.2)$ & $104(34.2)$ & $200(65.8)$ & \\
\hline Yes & $90(22.8)$ & $26(28.9)$ & $64(71.1)$ & \\
\hline Acute myocardial infarction & & & & 0.261 \\
\hline No & $284(72.1)$ & $89(31.3)$ & 195 (68.7) & \\
\hline Yes & $110(27.9)$ & $41(37.3)$ & $69(62.7)$ & \\
\hline
\end{tabular}


Continuation of Table 1

\begin{tabular}{|c|c|c|c|c|}
\hline \multirow{3}{*}{ Independent Variables } & \multirow{3}{*}{$\begin{array}{l}\text { Sample } \\
\text { n }(\%)\end{array}$} & \multicolumn{3}{|c|}{ Difficulty with access } \\
\hline & & Yes & No & \\
\hline & & $\mathrm{n}(\%)$ & $\mathrm{n}(\%)$ & $\mathrm{p}$-value \\
\hline Osteoarticular Disease & & & & 0.040 \\
\hline No & $205(52.0)$ & $58(28.3)$ & $147(71.7)$ & \\
\hline Yes & $189(48.0)$ & $77(38.1)$ & $117(61.9)$ & \\
\hline Neoplasia & & & & 0.596 \\
\hline No & $356(90.4)$ & $116(32.6)$ & $240(67.4)$ & \\
\hline Yes & $38(9.6)$ & $14(36.8)$ & $24(63.2)$ & \\
\hline Stroke & & & & 0.859 \\
\hline No & $365(92.6)$ & $120(32.9)$ & $245(67.1)$ & \\
\hline Yes & $29(7.4)$ & $10(34.5)$ & $19(65.5)$ & \\
\hline Self-perception of health & & & & 0.002 \\
\hline Positive & $187(47.5)$ & $47(25.1)$ & $140(74.9)$ & \\
\hline Negative & $207(52.5)$ & $83(40.1)$ & $124(59.9)$ & \\
\hline Has a caregiver & & & & 0.052 \\
\hline No & $348(88.3)$ & $109(31.3)$ & $239(68.7)$ & \\
\hline Yes & $46(11.7)$ & $21(45.7)$ & $25(54.3)$ & \\
\hline Fall in the last 12 months & & & & 0.002 \\
\hline No & $271(68.8)$ & $76(28)$ & $195(72.0)$ & \\
\hline Yes & $123(31.2)$ & $54(43.9)$ & $69(56.1)$ & \\
\hline Hospitalization in the last 12 months & & & & 0.005 \\
\hline No & $337(85.5)$ & $102(30.3)$ & $235(69.7)$ & \\
\hline Yes & $57(14.5)$ & $28(49.1)$ & $29(50.9)$ & \\
\hline Frail & & & & $<0.001$ \\
\hline No & $283(71.8)$ & $75(26.5)$ & $208(73.5)$ & \\
\hline Yes & $111(28.2)$ & $55(49.5)$ & $56(50.5)$ & \\
\hline \multicolumn{5}{|l|}{ Characteristics Related to Access } \\
\hline Has health plan & & & & 0.007 \\
\hline Yes & $149(37.8)$ & $37(24.8)$ & $112(75.2)$ & \\
\hline No & $245(62.2)$ & $93(38.0)$ & $152(62.0)$ & \\
\hline \multicolumn{5}{|l|}{ Who pays for health plan } \\
\hline Older adult themselves & $100(67.1)$ & & & \\
\hline Others & $49(32.9)$ & & & \\
\hline Main Service Sought & & & & $<0.001$ \\
\hline Public & $272(69.0)$ & $108(39.7)$ & $164(60.3)$ & \\
\hline Private or health plan & $122(31.0)$ & $22(18.0)$ & $100(82.0)$ & \\
\hline Sought ER** SUS*** & & & & 0.516 \\
\hline Yes & $188(47.7)$ & $59(31.4)$ & $129(68.6)$ & \\
\hline No & $206(52.3)$ & $71(34.5)$ & $135(65.5)$ & \\
\hline Sought Private ER** & & & & 0.207 \\
\hline Yes & $94(23.9)$ & $26(27.7)$ & $68(72.3)$ & \\
\hline No & $300(76.1)$ & $104(34.7)$ & $196(65.3)$ & \\
\hline
\end{tabular}


Continuation of Table 1

\begin{tabular}{lllll}
\hline & Sample & \multicolumn{2}{l}{ Difficulty with access } & \\
Independent Variables & $\mathrm{n}(\%)$ & Yes & No & $\mathrm{p}$-value \\
\hline Private Appointment & & $\mathrm{n}(\%)$ & $\mathrm{n}(\%)$ & $\mathbf{0 . 0 5 2}$ \\
Yes & $132(33.5)$ & $35(26.5)$ & $97(73.5)$ & \\
No & $262(665)$ & $95(36.3)$ & $167(63.7)$ & \\
\hline Sought Specialist Care & & & & \\
Yes & $83(21.1)$ & $23(27.7)$ & $60(72.3)$ & $204(65.6)$ \\
No & $311(78.9)$ & $107(34.4)$ & & \\
Sought Family Health Strategy & & & & \\
Yes & $259(65.7)$ & $98(37.8)$ & $161(62.2)$ & $\mathbf{0 . 0 0 5}$ \\
No & $100(34.3)$ & $32(23.7)$ & $103(76.3)$ & \\
\hline
\end{tabular}

*Minimum wage at time of data collection (R\$88000); **ER: Emergency Room; ${ }^{* * * S U S: ~ U n i f i e d ~ H e a l t h ~ S y s t e m ~}$

Table 2. Factors associated with difficulty in accessing health services among community-dwelling older adults in Montes Claros, Minas Gerais, Brazil.

\begin{tabular}{|c|c|c|c|}
\hline Variable & Prevalence Ratio (adjusted) & Confidence Interval & $\mathrm{p}$ value \\
\hline \multicolumn{4}{|l|}{ Marital status } \\
\hline With partner & 1 & & \\
\hline Without partner & 1.21 & $1.05-1.38$ & 0.005 \\
\hline \multicolumn{4}{|l|}{ Can Read } \\
\hline Yes & 1 & & \\
\hline Not & 1.23 & $1.02-1.49$ & 0.040 \\
\hline \multicolumn{4}{|l|}{ Self-perception of health } \\
\hline Positive & 1 & & \\
\hline Negative & 1.13 & $1.01-1.30$ & 0.054 \\
\hline \multicolumn{4}{|l|}{ Frail } \\
\hline No & 1 & & \\
\hline Yes & 1.35 & $1.10-1.65$ & 0.003 \\
\hline \multicolumn{4}{|l|}{ Main Service Sought } \\
\hline Public & 1.32 & $1.17-1.50$ & 0.000 \\
\hline Private and health plans & 1 & & \\
\hline
\end{tabular}

\section{DISCUSSION}

In the present study, it was found that 33\% of older adults reported difficulty in accessing health services. This prevalence is high, which is an important finding, as older adults constitute a significant section of the demand for care within health services, due to their characteristics of comorbidities, frailty and their health conditions, which make them vulnerable ${ }^{8}$. Possibly, access to health services for older adults, as determined by the National Older Adult Health Policy ${ }^{19}$, is not being carried out in practice.

In a study conducted in João Pessoa in the northeast of Brazil, a difficulty of access to services caused by transport and geographical barriers was observed $^{20}$. However, in the present study $67 \%$ of older adults had access to the health services they sought. There is a progressive path of health policies 
aimed at older adults which must be improved and the access of which must be expanded to achieve full, equal and universal reach.

The significant predominance of women illustrates the phenomenon of the growing feminization of older adults population. This trend mainly occurs due to the difference in mortality by sex, which affects the growth rate of the male and female populations and which prevails in the Brazilian population, resulting in the greater survival of women ${ }^{2}$. One of the challenges of the feminization process of aging is to create social spaces within health services in order to motivate older women to have a social life, and to ensure their access to health services when required. This would prevent isolation and strengthen female self-esteem and autonomy ${ }^{2,21}$

In the present study it was found, in multiple analysis, that there was greater difficulty with access among older adults without a partner; those who could not read; who had negative self-perceptions of their own health and who were frail. Regarding the health services sought, it was found that older adults faced greater difficulties when attempting to access public services.

The greater difficulty of access among older adults without partners can be explained by to the absence of a companion to bring them to the services ${ }^{22}$. Research has shown that widowed, divorced or separated older people have difficulty walking, and that this and the lack of companionship in health care are determinants of problems related to the lack of demand for health services.

The relationship between poor reading and inferior health indicators, including greater difficulties in accessing health services, has already been well described ${ }^{21,23}$. Also in a study conducted in Ceará, it was found that low levels of education may potentiate a worsening of health, due to unhealthy habits caused by a lack of knowledge; greater exclusion and lower levels of information about seeking out health services as early as possible ${ }^{23}$.

The chances of seeking health services increase as individuals grow older and have lower levels of education $^{24}$, with greater demand expected to lead to greater difficulties in access ${ }^{11}$. Studies conducted in Germany, France and the $\mathrm{UK}^{25}$ also revealed that users with low levels of education face the greatest obstacles in using the health services they seek. The continued encouragement of literacy among older adults is needed, providing them with learning opportunities that will result in improved self-care and accountability for their health and the timely seeking out of health services ${ }^{26}$.

In the present study, older people with a negative self-perception of health and who were frail reported greater difficulties in accessing health services. Similar results were observed in studies conducted in São Paulo ${ }^{27}$ and Minas Gerais ${ }^{28}$. A negative perception of health may be related to the presence of morbidity, frailty and other conditions that determine a greater need for medical services. Under these conditions, the more frequent seeking out of such services also implies greater difficulties in access and use $e^{28}$.

The significant association between access and frailty, a syndrome that involves biological, psychological and social aspects and can negatively impact the social and personal life of older adults, can be understood through the greater need that was observed. Although frailty is a progressive condition, through effective access to health services adequate care can alleviate and prevent symptoms. With increasing frailty older adults have difficulty getting around and require help; the presence of a caregiver and such disorders are barriers for older adults when seeking and using health services ${ }^{29}$.

The present study found greater difficulties among older adults who sought the public health service. These difficulties were mainly related to a lack of transportation to get to the health service, a lack of financial resources, the absence of company, a perception of inefficient services and also due to geographical and architectural barriers that prevented or hindered access. In a similar manner, a study conducted in Paraná identified a negative perception among the population about public services, which they saw as offering poor care, with older adults reporting obstacles to obtaining treatment when seeking such services ${ }^{4}$. Such services presented problems related to the non-continuity 
of the programs carried out, mainly due to changes in government, and consequent changes in public health policies ${ }^{4}$. In a survey conducted in Maranhão $0^{30}$ access to public services was also considered poor due to the opening hours of basic health units, which operate during business hours, the lack of a telephone number to schedule appointments, and issues with poor organization.

In the present study, the fact that there was less difficulty in accessing private services among older adults can be explained by the significant portion of the participating population with health plans $(37.8 \%)$. In addition, about $70 \%$ of older adults paid for their own plans. Health insurance coverage among older adults in Brazil has grown rapidly and includes approximately five million people aged 60 and over, representing $29.4 \%$ of the total number of older adults in the country ${ }^{31}$.

Although not significant in the final model, in this study, the most sought after service was the FHS, and probable problems in this service may explain the greater difficulties in access to public services. Although FHS coverage is increasing across Brazil, inequity of access still persists. Providing quality care is one of the primary goals of health systems, but this intention alone is not always enough. Balancing demand with care capacity still seems to be a serious problem in relation to access to primary health care ${ }^{32}$. Despite these difficulties, the FHS has been able to minimize longstanding inequalities in access. It is believed that for a positive impact on access to be perceived by the population, more time will be needed for the FHS to become fully established ${ }^{33}$.

Longevity is paradoxical, as the benefits of living longer are offset by the possibility of chronic illness, physical and psychological decline, isolation, depression, and a reduction in social and economic status. With the increase of older people living in the community, there is a need for more qualified health care and a dependency for care that falls on both the health team and family members, as well as an increased demand for health services ${ }^{34}$.

Given this, there is much to be done if the Unified Health System is to provide an effective and efficient response to the health needs and demands of the older adult population. Access to the various health services needs to be expanded and all health professionals, especially those working in the primary care network, the gateway to health services, must be undergo continuous training and skill building to meet the needs of the older population. The greater the access to goods and services of society, the greater the quality of life during the aging process. In this context, health services play a fundamental role in health care, if the older adult population is to enjoy life with all that they have built. This requires investments that prioritize disease prevention; the control of chronic conditions and increased access to health services that enable older adults to live with well-being ${ }^{2}$.

The data of the present study should be interpreted in the light of certain limitations, such as the significant loss of older people between the beginning of the study (baseline) and the first wave. There is also the condition of the older adults, with its limitations, such as loss of functionality and cognitive ability, which may have hampered the answering of certain questions, since the questionnaire used was broad and the physical and mental tiredness of older adults may have been an impediment. It is suggested in other studies that data collection is performed at more than one time, in stages.

Although data from a larger longitudinal study were used in the present investigation, the information on access comes from a cross-sectional perspective. Cross-sectional studies have limitations regarding the temporal identification of the studied factors. There is a need for longitudinal studies on the theme that develop and validate access assessment tools and the quality of specific health services for older adults in view of the particularities of this segment of the population, and the lack of standardization in assessing the access and use of health services.

The results show that conditions related to difficulties in access are subject to intervention, which is fundamental for the health promotion and disease prevention among older adults, in order to avoid adverse medical outcomes, especially regarding the difficulties of using health services. Knowledge of the factors associated with difficulties in access among older adults allows health actions aimed at this group to be developed in order to minimize such difficulties ${ }^{15}$. 


\section{CONCLUSION}

Difficulty in accessing the health services sought was reported by a significant proportion of the older adult participants of the study. The main conditions associated with such difficulty were not having a partner; not knowing how to read; having a negative self-perception of one's own health and being classified as frail. In addition, greater difficulties were reported in seeking care from public services.
The present study demonstrates the need for investments aimed at the health of older adults, in order to ensure the care of this growing population. Older adults and health services are closely linked and the relationship between the two may reflect inequities that negatively impact the quality of life of this population, which depends on integrated and effective public policies.

Edited by: Tamires Carneiro de Oliveira Mendes

\section{REFERENCES}

1. Organização das Nações Unidas. Demografia econômica e envelhecimento Populacional [Internet]. [sem local]: ONU; 2018 [acesso em 11 nov. 2018]. Disponível em: https://nacoesunidas.org/?post_ type $=$ post\&s $=$ envelhecimento

2. Organização Mundial de Saúde. Relatório mundial de envelhecimento e saúde [Internet]. Genebra: OMS; 2015 [acesso em 2019 out 07]. Disponível em: https://sbgg.org.br/wp-content/uploads/2015/10/ OMS-ENVELHECIMENTO-2015-port.pdf

3. Miranda GMD, Mendes ACG, Silva ALA. O envelhecimento populacional brasileiro: desafios e consequências sociais atuais e futuras. Rev Bras Geriatr Gerontol [Internet]. 2016 [acesso em 18 nov. 2018];19(3):507-19. Disponível em: http:// www.scielo.br/pdf/rbgg/v19n3/pt_1809-9823rbgg-19-03-00507.pdf

4. Scolari GAS, Rissardo LK, Baldissera VDA, Carreira L. Unidades de pronto atendimento e as dimensões de acesso à saúde do idoso. Rev Bras Enferm [Internet]. 2018 [acesso 18 nov. 2018];71(Suppl 2):811-7. Disponível em: http://www. scielo.br/scielo.php?script $=$ sci_arttext\&pid $=$ S003471672018000800811\&lng=en\&tlng=en

5. Paim J, Travassos C, Almeida C, Bahia L, Macinko J. The Brazilian health system: history, advances, and challenges. Lancet [Internet]. 2011 [acesso 17 nov. 2018]; 377(9779):1778-97. Disponível em: https://www.sciencedirect.com/science/article/pii/ S0140673611600548?via\%3Dihub

6. Travassos C, Martins M. Uma revisão sobre os conceitos de acesso e utilização de serviços de saúde. Cad Saúde Pública. 2004;20 Supl 2:190-8.

7. Rissardo KL, Carreira L. Organização do serviço de saúde e cuidado ao idoso indígena: sinergias e singularidades do contexto profissional. Rev Esc Enferm USP [Internet]. 2014 [acesso 07 out. 2019];48(1):72-9. Disponível em: http://www.scielo. br/scielo.php?script $=$ sci_arttext\&pid $=\mathrm{S} 0080$ 62342014000100072\&lng=en. http://dx.doi. org/10.1590/S0080-623420140000100009

8. Pilger C, Menon MU, Mathias TAF. Utilização de serviços de saúde por idosos vivendo na comunidade. Rev Esc Enferm USP [Internet]. 2013 [acesso 18 nov. 2018]47(1):213-20. Disponível em: http://www.scielo.br/scielo.php?script=sci_ arttext\&pid=S0080-62342013000100027

9. Oliveira APC, Gabriel M, Poz MRD, Dussault G. Desafios para assegurar a disponibilidade e acessibilidade à assistência médica no Sistema Único de Saúde. Ciênc Saúde Colet [Internet]. 2017 [acesso 21 out. 2019];22(4):1165-80. Disponível em: http://www. scielo.br/scielo.php?script=sci_arttext\&pid=S141381232017002401165\&lng=pt. http://dx.doi. org/10.1590/1413-81232017224.31382016

10. Figueira MCS, Silva WP, Silva EM. Acesso aos serviços da Atenção Primária em Saúde: revisão integrativa da literatura. Rev Bras Enferm [Internet]. 2018 [acesso em 26 fev. 2019];71(3):1178-88. Disponível em: http://www. scielo.br/scielo.php?script $=$ sci_arttext\&pid $=$ S0034$71672018000301178 \& \operatorname{lng}=$ en\& $\mathrm{nrm}=$ iso\&tlng=pt

11. Viegas APB, Carmo RF, Luz ZMP. Fatores que influenciam o acesso aos serviços de saúde na visão de profissionais e usuários de uma unidade básica de referência. Saúde Soc [Internet]. 2015 [acesso em 26 fev. 2019];24(1):100-12. Disponível em: http://www. scielo.br/scielo.php?script $=$ sci_arttext\&pid $=$ S010412902015000100100\&lng=pt\&tlng $=p t$ 
12. Assis MMA, Jesus WLA. Acesso aos serviços de saúde: abordagens, conceitos, políticas e modelo de análise. Ciênc Saúde Colet [Internet]. 2012 [acesso 21 out. 2019];17(11):2865-75. Disponível em: http://www. scielo.br/scielo.php?script $=$ sci_arttext\&pid=S1413$81232012001100002 \& \operatorname{lng}=\mathrm{pt}$

13. Ramos GCF, Carneiro JA, Barbosa ATF, Mendonça JMG, Caldeira AP. Prevalência de sintomas depressivos e fatores associados em idosos no norte de Minas Gerais: um estudo de base populacional. J Bras Psiquiatr [Internet]. 2015 [acesso em 12 nov. 2017];64(2):123-31. Disponível: http://www. scielo.br/scielo.php?script $=$ sci_arttext\&pid=S004720852015000200122\&lng $=$ pt\&tlng $=$ pt

14. Instituto Brasileiro de Geografia e Estatística. Panorama. Populações Estimadas, Cidades, 2018 [Internet]. Rio de Janeiro: IBGE; 2018 [acesso em 12 nov. 2017]. Disponível em: https://cidades.ibge.gov. $\mathrm{br} / \mathrm{brasil} / \mathrm{mg} / \mathrm{montes}$-claros/panorama

15. Carneiro JA, Cardoso RR, Durães MS, Guedes MCA, Santos FL, Costa FM, et al. Frailty in the elderly: prevalence and associated factors. Rev Bras Enferm. 2017;70(4):747-52.

16. Bonello AALM, Correa CRS. Acesso aos serviços básicos de saúde e fatores associados: estudo de base populacional. Ciênc Saúde Colet [Internet]. 2014 [acesso 04 abr. 2019];19(11):4397-4406. Disponível em http://www.scielo.br/scielo.php?script=sci_ arttext\&pid=S1413-81232014001104397\&lng=pt\&t $\operatorname{lng}=\mathrm{pt}$

17. Brasil. Ministério da Saúde, Departamento de Análise de Situação de Saúde. Vigilância de fatores de risco e proteção para doenças crônicas por inquérito telefônico: Vigitel 2010. Brasília, DF: MS; 2011.

18. Rolfson DB, Majumdar SR, Tsuyuki RT, Tahir A, Rockwood K. Validity and reliability of the Edmonton Frail Scale. Age Ageing [Internet]. 2006 [acesso em 26 fev. 2019];35(5):526-29. Disponível em: https://academic.oup.com/ageing/ article/35/5/526/9782

19. Brasil. Ministério da Saúde. Portaria no 2.528 de 19 de outubro de 2006. Aprova a política nacional de saúde da pessoa idosa. Diário Oficial da União. Out. 2006.

20. Amaral FLJS, Motta MHA, da Silva LPG, Alves $\mathrm{SB}$. Fatores associados com a dificuldade no acesso de idosos com deficiência aos serviços de saúde. Ciênc Saúde Colet [Internet]. 2012 [acesso em 26 fev. 2019];17(11):2991-3001. Disponível em: http://www. scielo.br/scielo.php?script $=$ sci_arttext\&pid=S141381232012001100016\&lng=pt\&tlng $=$ pt
21. Almeida APSC, Nunes BP, Duro SMS, Facchini LA. Determinantes socioeconômicos do acesso a serviços de saúde em idosos: revisão sistemática. Rev Saúde Pública. 2017;51(50):1-15.

22. Domingues MA, Ordonez TN, Lima-Silva TB, Torres MJ, Barros TC, Florindo AA. Redes de relações sociais dos idosos residentes em Ermelino Matarazzo, São Paulo: um estudo epidemiológico. Rev Bras Geriatr Gerontol [Internet]. 2013 [acesso em 26 nov. 2019];16(1):49-59. Disponível em: http://www. scielo.br/scielo.php?script $=$ sci_arttext\&pid $=\mathrm{S} 1809$ 98232013000100006\&lng=pt\&tlng=pt

23. Pereira DS, Nogueira JAD, Silva CAB. Qualidade de vida e situação de saúde de idosos: um estudo de base populacional no Sertão Central do Ceará. Rev Bras Geriatr Gerontol [Internet]. 2015 [acesso 08 maio 2019];18(4):893-908. Disponível em: http:// www.scielo.br/pdf/rbgg/v18n4/pt_1809-9823rbgg-18-04-00893.pdf

24. Louvison MCP, Lebrão ML, Duarte YAO, Santos JLF, Malik AM, Almeida ES. Desigualdades no uso e acesso aos serviços de saúde entre idosos do município de São Paulo. Rev Saúde Pública [Internet]. 2008 [acesso 20 out. 2019];42(4):733-40. Disponível em: http://www.scielo.br/scielo.php?script $=$ sci_ arttext\&pid=S0034-89102008000400021\&lng=en

25. Ferreira MRJ, Mendes AN. Mercantilização nas reformas dos sistemas de saúde alemão, francês e britânico. Ciênc Saúde Colet [Internet]. 2018 [acesso em 26 fev. 2019];23(7):2159-70. Disponível em: http://www. scielo.br/pdf/csc/v23n7/1413-8123-csc-23-07-2159.pdf

26. Paskulin LMG, Bierhals CCBK, Valer DB, Aires M, Guimarães NV, Brocker AR, et al . Alfabetização em saúde de pessoas idosas na atenção básica. Acta Paul Enferm [Internet]. 2012 [acesso 21 out. 2019];25(Spec 1):129-35. Disponível em: http://www.scielo. br/scielo.php?script $=$ sci_arttext\&pid=S010321002012000800020\&lng=pt

27. Loyola Filho AI, Firmo JOA, Uchôa E, Lima-Costa MF. Fatores associados à autoavaliação negativa da saúde entre idosos hipertensos e/ou diabéticos: resultados do projeto Bambuí. Rev Bras Epidemiol. 2013;16(3):559-71.

28. Medeiros SM, Silva LRS, Carneiro JA, Ramos GCF, Barbosa ATF, Caldeira AP. Fatores associados à autopercepção negativa da saúde entre idosos não institucionalizados de Montes Claros, Brasil. Ciênc Saúde Colet [Internet]. 2016 [acesso 19 nov. 2018];21(11):3377-86. Disponível em: http://www. scielo.br/scielo.php?script $=$ sci_arttext\&pid $=\mathrm{S} 1413$ 81232016001103377\&lng=pt\&tlng=pt 
29. Fernandes HC. O acesso aos serviços de saúde e sua relação com a capacidade funcional e a fragilidade em idosos atendidos pela Estratégia Saúde da Família [dissertação]. São Paulo: Universidade de São Paulo; 2010.

30. Reis RS, Coimbra LC, da Silva AAM, Santos AM, Alves MTSSB, Lamy ZC, et al . Acesso e utilização dos serviços na Estratégia Saúde da Família na perspectiva dos gestores, profissionais e usuários. Ciênc Saúde Colet [Internet]. 2013 [acesso 19 nov. 2018];18(11):3321-31. Disponível em: http://www. scielo.br/scielo.php?script=sci_arttext\&pid=S1413$81232013001100022 \& \operatorname{lng}=\mathrm{pt} \& \operatorname{tlng}=\mathrm{pt}$

31. Malta DC, Stopa SR, Pereira CA, Szwarcwald CL, Oliveira M, Reis AC. Cobertura de Planos de Saúde na população brasileira, segundo a Pesquisa Nacional de Saúde, 2013. Ciênc Saúde Colet [Internet]. 2017 [acesso em 19 nov. 2018];22(1):179-90. Disponível em: http://www. scielo.br/scielo.php?script=sci_arttext\&pid=S1413$81232017000100179 \& \operatorname{lng}=$ pt\&tlng $=$ pt
32. Rocha SA, Bocchi SCM, Godoy MF. Acesso aos cuidados primários de saúde: revisão integrativa. Physis [Internet]. 2016 [acesso em 19 nov. 2018];26(1):87-111. Disponível em: http://www. scielo.br/scielo.php?script $=$ sci_arttext\&pid=S010373312016000100087\&lng=pt\&tlng=pt

33. Andrade MV, Noronha K, Barbosa ACQ, Rocha TAH, Silva NC, Calazans JA, et al. A equidade na cobertura da Estratégia Saúde da Família em Minas Gerais, Brasil. Cad Saúde Pública [Internet]. 2015 [acesso em 19 nov. 2018];31(6):1175-87. Disponível em: http://www.scielo.br/scielo.php?script=sci_ arttext\&pid=S0103-73312016000100087\&lng=pt\& tlng $=\mathrm{pt}$

34. Silva RM, Brasil CCP. A quarta idade: o desafio da longevidade. Ciênc Saúde Coletiva [Internet]. 2016 [acesso em 19 nov. 2018];21(11):3631-2. Disponível em: http://www.scielo.br/scielo.php?script=sci_ arttext\&pid=S1413-81232016001103631\&lng=pt\&t $\operatorname{lng}=\mathrm{pt}$ 